الخامسة2

\title{
بنية الخطاب في لغة الزي الآشوري
}

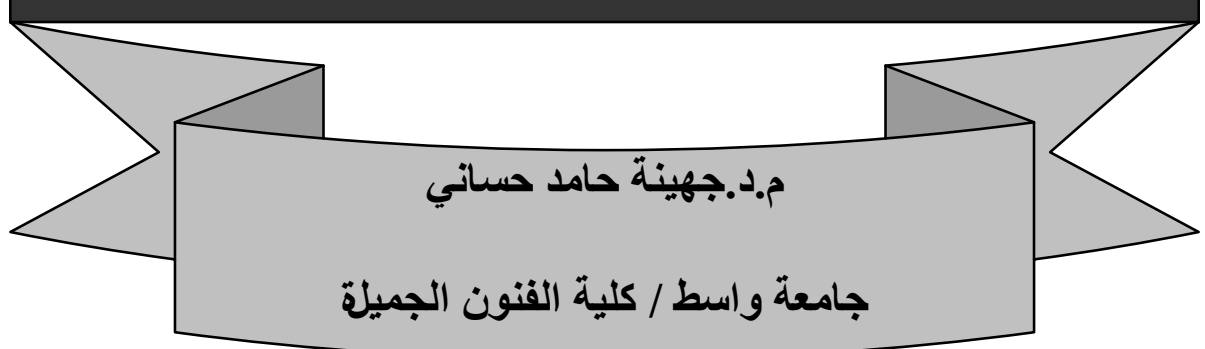

المقدمة :

تحمل النصوص الاشورية [الأزياء] في داخلها نشاطات فكرية كبيرة [سمات اجتماعية ] انعكست على وفق معالجاتها الثكلية المخصصة بمو اضيع ثقافية تتعدى مرحلة التحليل الذهني الخاص إلى مرحلة البناء الإنساني العام. إنّ بحثٔ كهذا [بنية الخطاب في لغة الزي الآثوري] يهدف إلى اتساع دائرة التأريخ و الحث على رؤيته من جديد، فالعمليه ليست بالرصف المتلاحق لتاريخ الأزياء أو بتفكيك مفرداتها، بل هي عملية مو اكبة تحولية تستثمر تلك العقود الثابتة وتنطلق بها إلى الترتيب و التنظيم المعرفي المميز على وفق المنهج البنيوي تحت ثثلاثة محاور:-

$$
\begin{aligned}
& 1 \text { ـ لغة الزي الآشوري. } \\
& 2 \text { - فرضيات في بنية الزي الاشوري. } \\
& 3 \text { - أنماط الخطاب. }
\end{aligned}
$$

و هنا نود الإشارة إلى أننا قمنا بدر اسة زي الملكك وملحقاته الخارجية من حلي وأدوات؛ لأسباب تتعلق بكثرة العينات الملكية في الفترة الآشورية من الحضارة الر افدينية، ومن خلالها يمكن إثبات صحة فرضنا الر افض لتحديد خطاب الزي الآشوري تحت مستويات الطبقة الاجتماعية ليس استناداً لما جاءت به الدر اسات السابقة، و انما لتصنيفه على وفق وظائفه المتاحة طبقاً لما جاءت به نتائج هذه الدر اسة، فلم يعد هناللك تخصيص محدد؛ لانْ رداء الملك - مثنلا- حاكى رداء الجندي في 


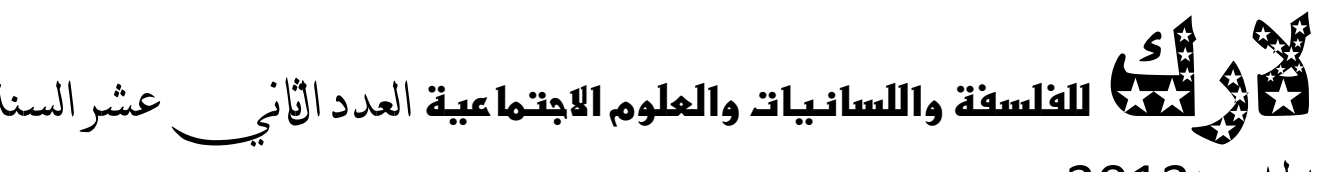

$$
\text { مداها المعرفي في التحليل، ورداء المتعبد في الطقوس الدينية...إلخ. وهي دراسة جديدة لم تطرق سابقأ وقد أخذت }
$$

The structure of the speech in the language of the Assyrian uniform

\section{Introduction:}

Assyrian texts( fashion ) carry out inside it a great deal of intellectual activity [ social attributes] reflected on formalism processors committed to the themes of cultural according to its processors exceed the mental analysis phase to the construction phase of the General construction of humanitarian stage. That such research structure in the language of discourse of Assyrian uniform [aimed at widening circle of history and prodding to see it again], the process is not a successive collocation to the history of fashion or dismantle its vocabulary to each other. It is a process of transformative keep investing that fixed contracts and launched them into the arrangement and organization of cognitive featured on according to the structural approach fewer than three themes-

1- The language of Assyrian uniform.

2- Assyrian uniform structure hypotheses.

3- The speech patterns.

Here we would like to note that we have studied the king's costume $\&$ its Peripherals external costume, and tools for reasons of abundance of the royal's property samples in the period of Assyrian civilization, 


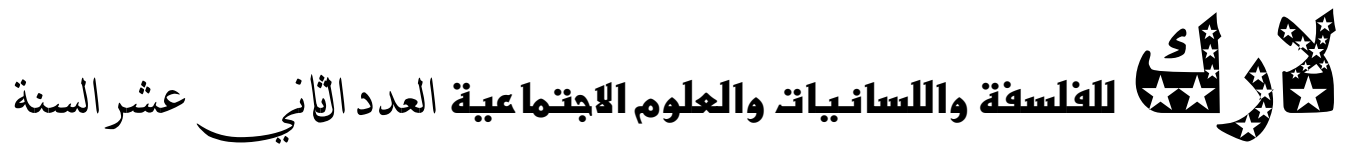
الخامسة2013

Mesopotamian, and which can be validated our Assumption which refuses to identify the speech of Assyrian uniform. Below the levels of social class based on what came by previous studies, but classified according to the functions available according to the results of this study, there is no longer a specific allocation because the dress of the King, for example, simulated the dress of the soldier in the war, and emulated the dress of the worshiper in religious rituals ... etc. A new study that has not been touched previously taken a range of knowledge in the analysis, and reading.

\section{لغة الزي الآشوري :-}

تبدو الأزياء الاشورية صلبة وخشنة، لكثرة ما عليها من رسوم وزخارف عبرت عن البطش

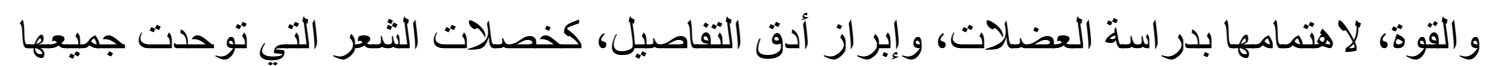

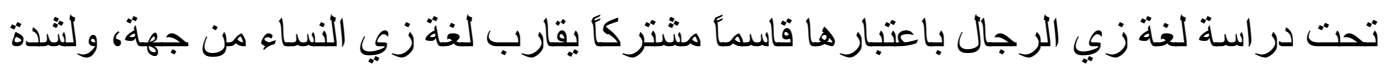

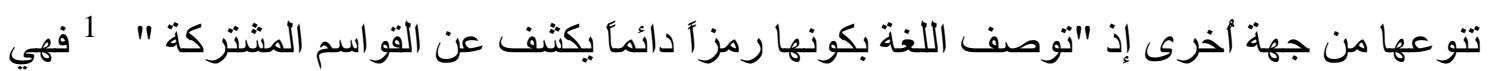
التي تجعل من موضو عة الزي سمة إنسانية متحركة يؤول الفرد من خلالها إلى تعريف نفسه بإزاء

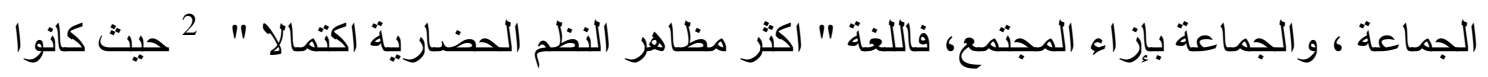
يرتدون الثال، و هو قطعة مستطيلة من القماش يلف أحد طرفيه حول الرقبة، ويلف الطرف الآخر

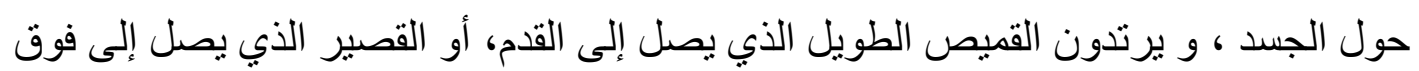
1 شتراوس، كلود ليفي: الأسطورة والمعنى، ترجمة: د.شاكر عبد الحميد، ط 1، دار الثؤو ن الثقافية، بغداد،

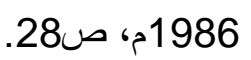

2 دوزي، اينو : جلية علم الاجتماع بين الرمز والإثارة ، ترجمة: قيس النوري، دار الثؤون الثقافية ، بغداد

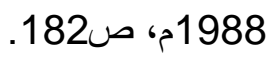


الخامسة2013

الركبة ذو الكم القصير الضيق الذي يصل إلى فوق المرفق بقليل، و وقد طرز الزي برموز 3 عدّة، منها:-

- خطوط هندسية بسيطة : متقطعة أو مستمرة ، مستقيمة أو متكسرة ، متوازية أو متشابكة ، أفقية

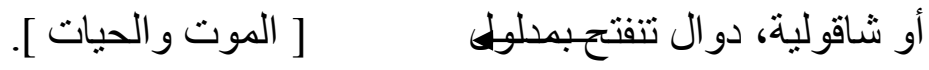

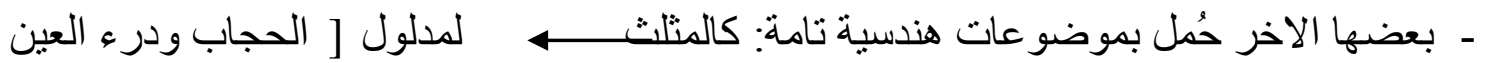
]، و المربع [ حارس أمين من العين و الحسد ] ]، في حين دخلت الدائرة يمعنىه [الديمومة والبقاء- وحركة الكون].

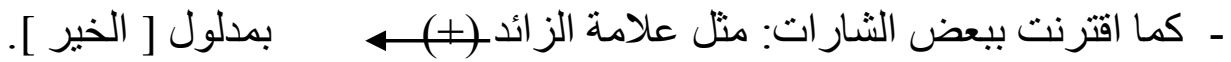

ـ أما الصور الحية للنباتات و الاشجار فقد " كانت عبارة عن شكل لنخلة في الغالب مؤداه بشكل

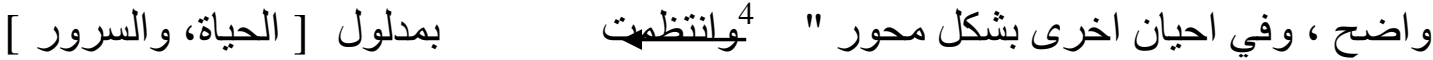
و الوروبـولهلاز هار وقد صورت بمدلول [العطاء و الربيع اللؤلؤي].

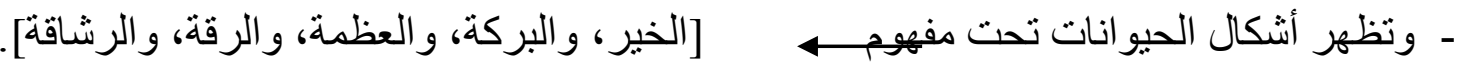

تنم استنتاج مدلول هذه الرموز من خلال استقراء المصادر التالية: الجاد، وليد: الأزياء والأثاث، حضارة العراق، الجزء4، دار الحرية للطباعة، جامعة بغداد، 1985م، ص341 ، 342، 343. و حسين، تحية كامل: تاريخ

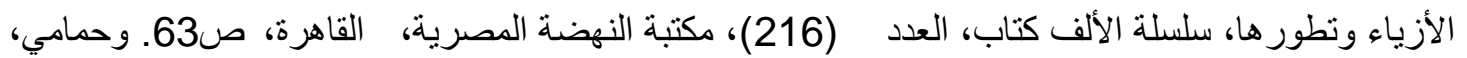

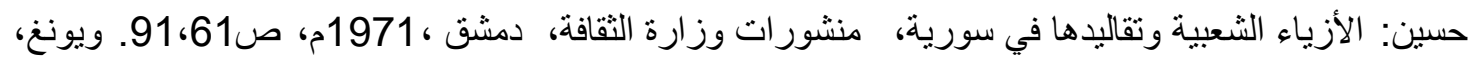

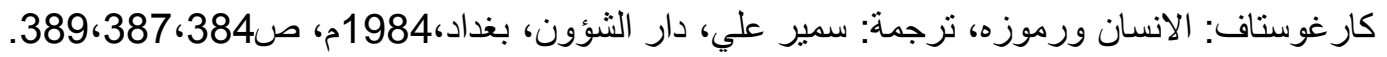
4 الجاد، وليد: الأزياء و الأثاث، حضارة العراق، ص335. 


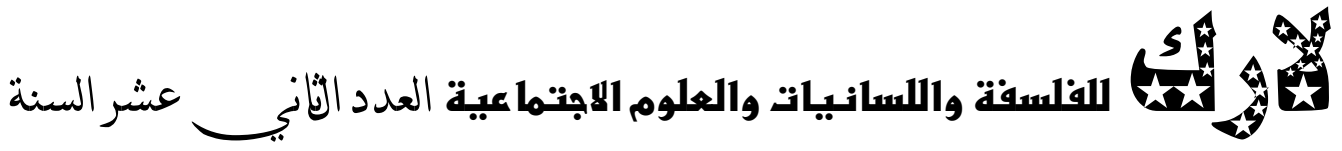
الخامسة2013

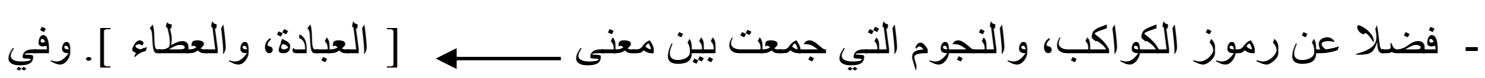
بعض الأزياء أثنير إلى الكواكب، و النجوم ايضأ من خلال اللمعان حيث تعدى الامر ليشمل دلالة القيم اللونية في:-

ارتبط بمدلول اللمعان الذي أثير بو اسطته إلى معنى العبادة، و العطاء،

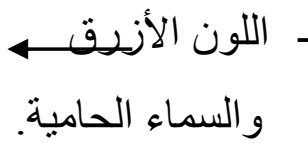

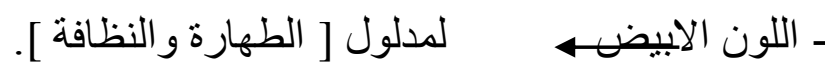

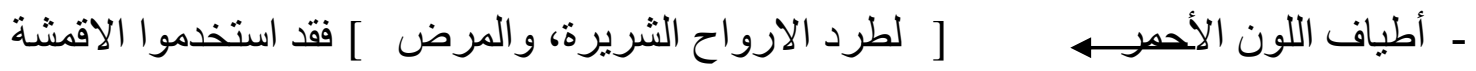
الحمر اء ذات اللون القوية بإشعاعها لتدثير وتغطية المتوفى كما رمز اللون الأحمر إلى القوة الجسدية، و النشاط، و الحرب، و الثورة، ويدخل اللون الأحمر مع الأزرق في مناسبات عدة.

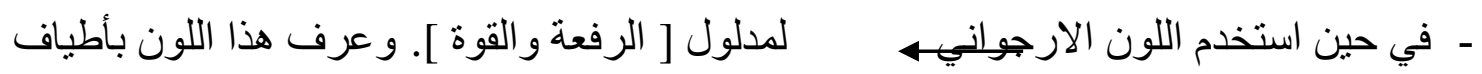
عدة استخلصت من قو اقع البحار.

ـ ـ وأدخل اللون الاسودـــــاستضافة مع اللون الابيض في الأزياء الاشورية، فلم يكن يرمز إلى الحزن حيث ورد استخدام اللون الاسود على شكل خيط يوضع حول الرقبة او رأس المريض للتخلص من بعض الأوجاع الجسمية.

ميز الاشوريون بين اللونين الأخضر والأصفر في تعابير هم فضلا عن درجات الصبغة الصفر اء المستخلصة من الكركم والزعفران، فظهرت ألوان الأصفر المائل إلى البرتقالي، والأحمر المصفر وهو لون الذهب، كما عرفو ا استخلاص أطياف اللون الأحمر القاني ولونه الوردي من ديدان الأشجار. وقد أتسعت هذه القضية لتشمل الحلي من الأقر اط و الأساور ، ومنها ما يلبس حول المعصم وحول العضد فضلا عن الخواتم الدبابيس والأسلحة، وهي محملة بذات النصوص الخطابية لتلك الرموز و العلامات البنائية، فلا هي الواقع و لا من الواقع في شيء بل شيء، من المعتقد يشترك معه 


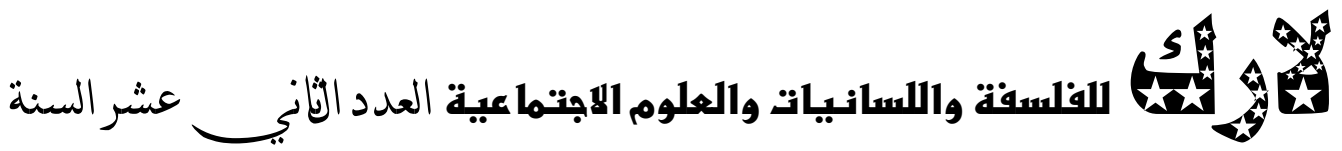
الخامسة2013

5

الزي في جذر واحد قصد أكثار الرزق، والحماية. فاللغة هي "عملية تفريق وانشاء وليست بناء" حيث تتحقق الآلية البنائية مع الفقرة اللاحقة من هذه الدر اسة.

\section{فرضيات في بنية الزي الآشوري :-}

ينشد سياق الزي في هذا المحور منطقً افتر اضياً لا يقينياً يعمل على برمجة علائق النص وربطها بدرجة من التمظهر والانزياح إلى مستويات من الإيحاء الرمزي صوب غموض حاد من خطوط، وسطور ، وقيم لونية، وكتل شكلية، ومساحات فضائية ...إلخ. ينعكس بو اسطتها قانون داخلي (دليل) مكتفٍ بذاته مغلق البنى الفكرية على نحو متميز آخذاً معه الذوق السائد على وفق معادل شكلي تتوقف علية البنية بأربع فرضيات : اثتتان منها تبحثان في طبيعة العلاقة بين مكونات الكل و الأجز اء، و اثنتان تبحثان مع طبيعة الإدر الك الحسي للصور و الأشكال في :-

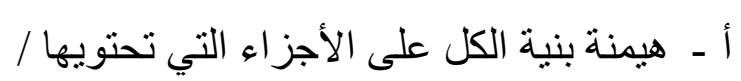

بين الجثنالتيون أن إدر الك الأشياء كمجموعة مبنية لا فاصل بين عناصر ها المكونة أكثر و اقعية من كل الاجز اء، فقد بنطوي الجزء على قيمة عقلية من دون صباغة مفاهيم عقلية، أو من دون الأخذ بطابع الأشياء وتدقيقها في ضمن إطار ها الكلي. على غرار ذلك قدمت البنبة بأنها "مجمو عة ما بحيث تكون هنالك أسبقية منطقية للكل على الأجزاء" 6، كالتي تظهر في شريط المسح البصري المنظم للعناصر الأثية:-
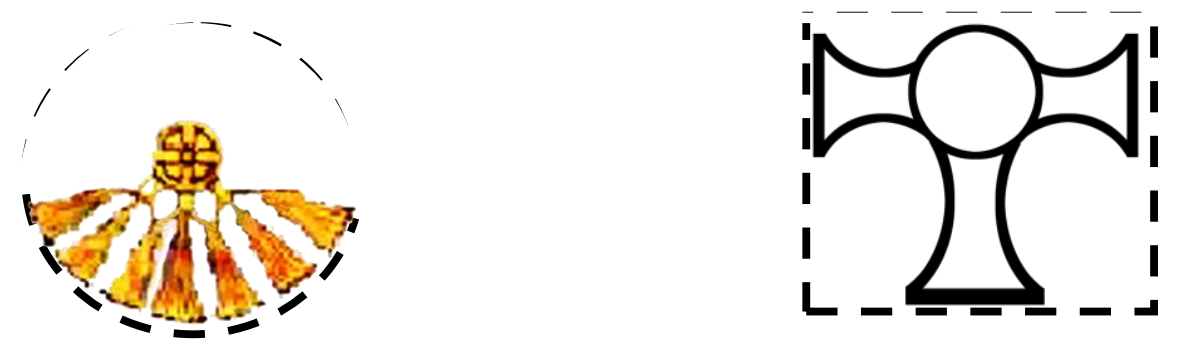

$$
5 \text { دوزي، اينو: جدلية علم الاجتماع بين الرمز والاشارة، ص399. }
$$

6 يفوت، سالم: ليفي شتراوس و عقم الفلسفة ، قضية البنيوية دراسة ونماذج، ترجمة: الدكتور عبد السلام المسدي ، المطبعة

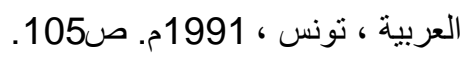




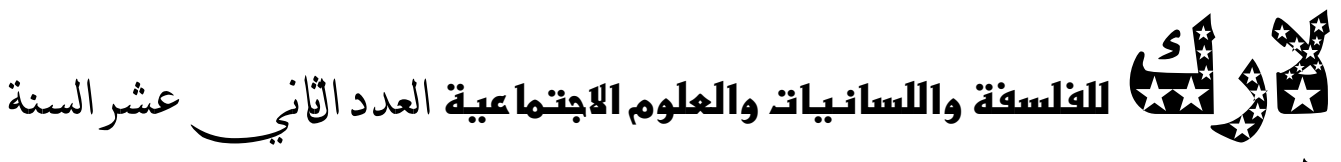

شكل (1) يصور دال أقر اط الأذن 7 ببنية المربع شكل (2) يصور دال حلية الخيل 8 ببنية الدائرة

تقر أ المتو اليات الثكلية (1)، و (2) على التو الي ( مربع ــ دائرة ) في ضمن إطار كلي من دون الاخذ بتلك الفو اصل الجزئية المتحققة، وهي بذلك تتفي الحكم القبلي للتربية البصرية و القائل "

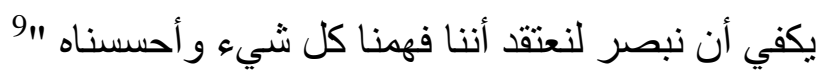
ب- المقاربة البنائية بين الكل والاجزاء :

لا يهيمن الكل على الأجزاء بل ينطلقان معا نحو بؤرة العمل الفني، ويؤسسان معه علاقة . متكاملة بين الأجز اء، فلا يجوز أخذ الكل دون الجزء، وكذلك الجزء دون الكل، فإذا حذفنا أو أضفنا جز ءاً من ذلك الكل اختل المعطى البصري و انجرف في صورة أخرى وبفكرة مختلفة؛ لذلك نظرت الجشتالت إلى تلك الظواهر على أنها "مجاميع متر ابطة تؤلف وحدات مستقلة تكثف عن مضامينها الجزئية وقو انينها الخاصة" 10، كما في مقاربة بساطة زي الملاك، وتعري

\footnotetext{
${ }^{7}$ Weston, Pauline Thomas: Ancient Costume - c800 B.C. Early Assyrian Costume History \& Pictures, p7.
}

${ }^{8}$ Weston, Pauline Thomas: Ancient Costume - c800 B.C. Early Assyrian Costume History \& Pictures, p6.

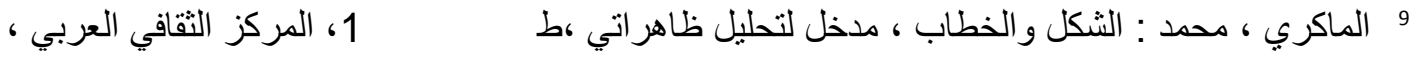

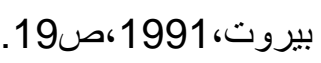

10 للمزيد راجع : يونس، عبد الحميد : اللغة الفنية، مجلة عالم الفكر، المجلد (2)، العدد (1)، مطبعة الحكومة

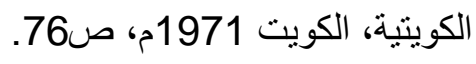


الخامسة2013

رأسه بالعبادة، فإذا حذفنا أحدهما انهار المعنى البنائي للعبادة، وانضمرت الفكرة لصالح مفهوم

$$
\text { جـــ الصورة غير متوقع. }
$$

يتوقف إدر الك الصور( Figures ) على إدر الك الأرضية ( Ground found ) شريطة وجود فارق بينهما لغرض التمايز الشكلي، فلا يمكن ادر اكهما معاك، لأن البنية تبحث دائما عن "الثابت بين تللك الاختلافات السطحية" 11، كما في تتاوب ظهور وريقات زهرة (اللوتس ) 12 بين صليبين، فإذا ظهر الاول (×) كصورة اختفى الأخر كأرضية (+)، وبالعكس يتناوب ظهور كل منهما على حساب الاخر. لاحظ المخطط التالي :
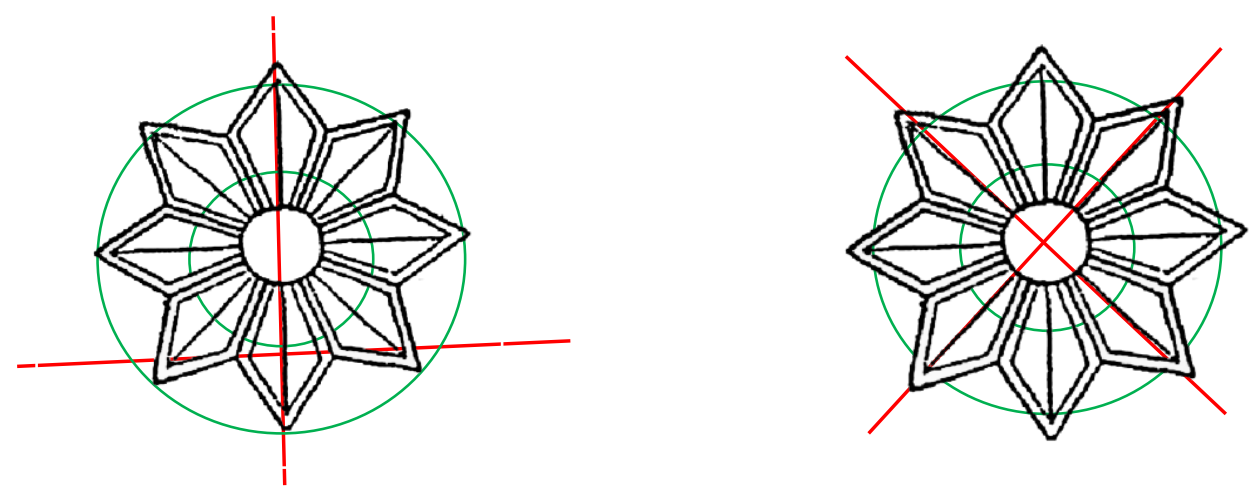

$$
\text { شكل (3) يوضح الصليب (×) كصورة }
$$

11 للمزيد راجع : جسام ، بلاسم محمد : التحليل السيميائي لفن الرسم - مبادئ وتطبيقات، أطروحة دكتور اه فلسفة ،

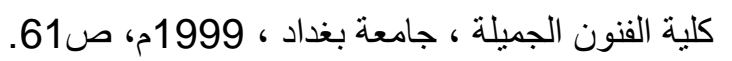

${ }^{12}$ Hall, James. 1994." Illustrated Dictionary of Symbols in Eastern and Western Art ". (Illustrated) Chris Puleston. London: John Murray. P 151. 


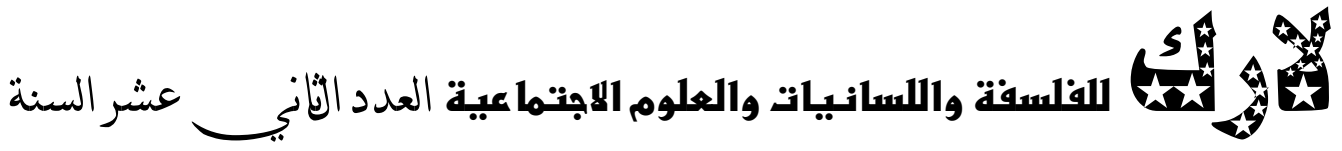
الخامسة2013

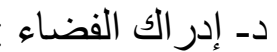
يؤثر عمق الفضاء على بنية الصورة فضلا عن عمق الصورة ذاتها لإحداث الفهم المباشر؛ وهو أمر ينطبق على موضو عات الطبيعة الانسانية المحدد بقو انين الإدر الك وهي : 1 ـ قانون العظم ـ الثكل الصغير يبرز منفصلا عن عمق أكثر كبرا. 2 ـ قانون البساطة ـ الثكل البسيط أبرز من الشكل المعقد. 3 قانون الانتظام والتقابل ـ يتعلق الامر بالتقسيم المنظم و التقابل لعناصر شكل معين. 4 ـقانون الاختلاف ـ الثكل المبني بكيفية غريبة يبرز في الفضاء بشكل أفضل.

إنها قو انين لا تقف عند التصنيف ورصد الاشكال وهي بحاجة إلى فهم الإدر الك كيف يحدث ويتشكل طبق نظرية "أرنهايم" من :-

$$
1 \text { - إن كل شيء يتم إدر اكه يؤخذ حرفياً :- }
$$

إذ يتعلم الانسان بالتدريج وبطريقة أكثر كفاءة رؤية الأجزاء المخفية عبر قطع الأجزاء المرئية في بنية واحدة لتشكيل الصور كاملة، " فالطفل يولا عادة ويتطور في المجتمع البشري بمحاذاة تشكيل الرمز و إنشاء المواضيع "13، و أول شيء يقوله هو أهم شيء يعرب عن إدر اكه .

$$
2 \text { - وجود المعنى الواسع للشيء في المدرك الرمز:- }
$$

و هو لا يصبح في ذات الثيء بل بعلائقه بين المجمو عات الأخرى لإثر اء الفكرة تحت الرؤية الاولى المدركة، سو اء كانت الصورة مكتملة ( واقعية ) أم غير مكتملة ( مجردة ) تبني علائقها الاستدلالية بربط الوسط الرمزي الانسان بالطبيعة من كتل ،و ألو ان ، و عمق ، وفر اغ....وما 13 سبيلا ، محمد وآخرون : الفلسفة الحديثة ، نصوص مختارة ، ط 1، دار المأمون ، الرباط ، 1996م، ص160. n n 
الخامسة2013

إلى ذلك من ادوات الاتصال. وقد صفها ( يونج ) " بأفضل الصيغ الممكنة للتعبير عن حقيقة مجهولة نسبياً، و لا يمكن توضيح أكثر من ذللك بأي وسيلة أخرى" 14، إلا إنها تبقى في الوقت ذاته بحاجة إلى در اسة أوسع للكثف عن الحقائق المستورة " فالفكر الرمز لا يحمل الحقائق بل يستر ها في جوفه ويشير إليها من خلال التاويل و القر اءة "15.

ثم تظهر الحاجة إلى التدريب على المو اصلة كي تدرك قو اعد لغة الزي المسكوكة بنائياً وسط أبعاد انفتاحية تجاوزت فكرة الفهم المغلق بأو اصر عقلانية تعمل على الحد من التناقضات، بل لا تسمح لها بالظهور إلى سلطة النظام الثكلي. وإن حدث بعض التفاوت في الخطاب فهو تفاوت وظيفي وليس لغوياً حيث تتحدد العملية بطريقة التعبير والمخاطبة الاسلوبية في المحور القادم من هذه الدر اسة " فلا يوجد شخصان بستعملان اللغة بالطريقة عينها تماماً "16.

\section{انماط الخطاب :-}

استنادآ لما سبق، سوف نطلق تسمية ( الانسان البنائي ) على الفنان الر افديني " الذي لا نعرفه بأفكاره، و لا بلغته و إنما بخياله أو بطريقة تصوره للأشياء"17، فلا يدع الطبيعة تطغى عليه فيجيء بنوع من القراءة كتحصيل حاصل عن عملية تجميع البنية التركيب. على غرار ذللك ظهر عندنا في هذا المحور أربعة أنواع من الرموز الخطابية قدمت على أنها تعميمات ملائمة للو اقع بصورة

${ }^{14}$ ينر : عبد الحميد ، شاكر : العملية الابداعية في فن التصوير ، سلسلة عالم المعرفة ، رقم ( 109) ن المجلس

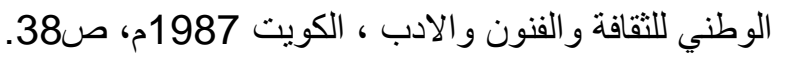

15 العروي : مفهوم الايديولوجيا ، الفلسفة الحديثة نصوص مختارة ، ص100.

16 غارمادي ، جولييت : اللسانية الاجتماعية ، ت: د. خليل احمد خليل ، ط 1، دار الطليعة ، بيروت ، 1990م، 


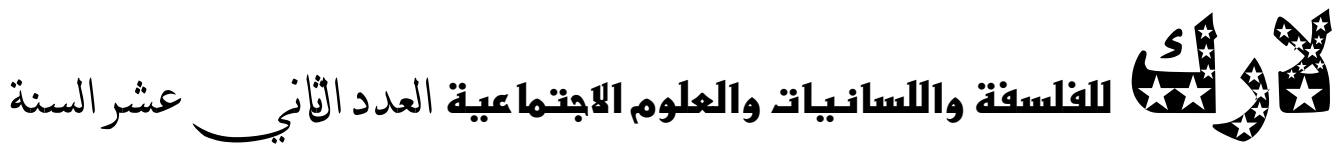
الخامسة2013

مطردة غير منسوخة، حيث تم اختيار الأنسب منها لتعريف المقادير ، ولنقل تللك الرموز من مستوى

$$
\text { الإقناع إلى الإثراء، و هي على النحو الآتي: }
$$

الخطاب الاول / صور الملك ( أشور بانيبال) في بدلة قصيرة ذات نهايات مشرشرة بشريط من حز ام الخيوط المعقودة من الأعلى والطليقة من الأسفل؛ وقد زين صدر بدلة الملك بحقول مستطيلة التكوين تشغلها زخارف دائرية تحوي على زهرة اللوتس التي تكرر طابعها إلانشائي مع زخرفة القماش، و عمامة الر أس العريضة من الأمام، و الضيقة من الخلف، فضلا عن تزيين أثرطتها المتدلية إلى الخلف بذات التكوين الزهري وقد اتسع هذا التكوين ليشمل كلا من دال الحلي في حلق الاذن ذي التكوين النصف زهري، وسوار اليد ذي الزهرة الكاملة.

يرتدي الملك حز امأ عريضأ مثبتأ بحز ام فوقه ذي ترتيب متناوب بين مربع مشغول بالوحدات الزهرية، و آخر محزز بخطوط أفقية منو ازية. كما شمل نمط التحزيز هذا دال الحز ام الكبير، ودال حذاء القدم الطويل فضلا عن ظهورهِ مع دال زخرفة الجواريب التي حُملت هي الاخرى بطابع التحزيز الافقي، والمائل، و المنكسر المتو اصل مع طابع زخرفة شريط الزي الموجود فوق الثريط المشرشر لرداء الملك. انظر المخطط التوضيحي للزي شكل رقم (5).

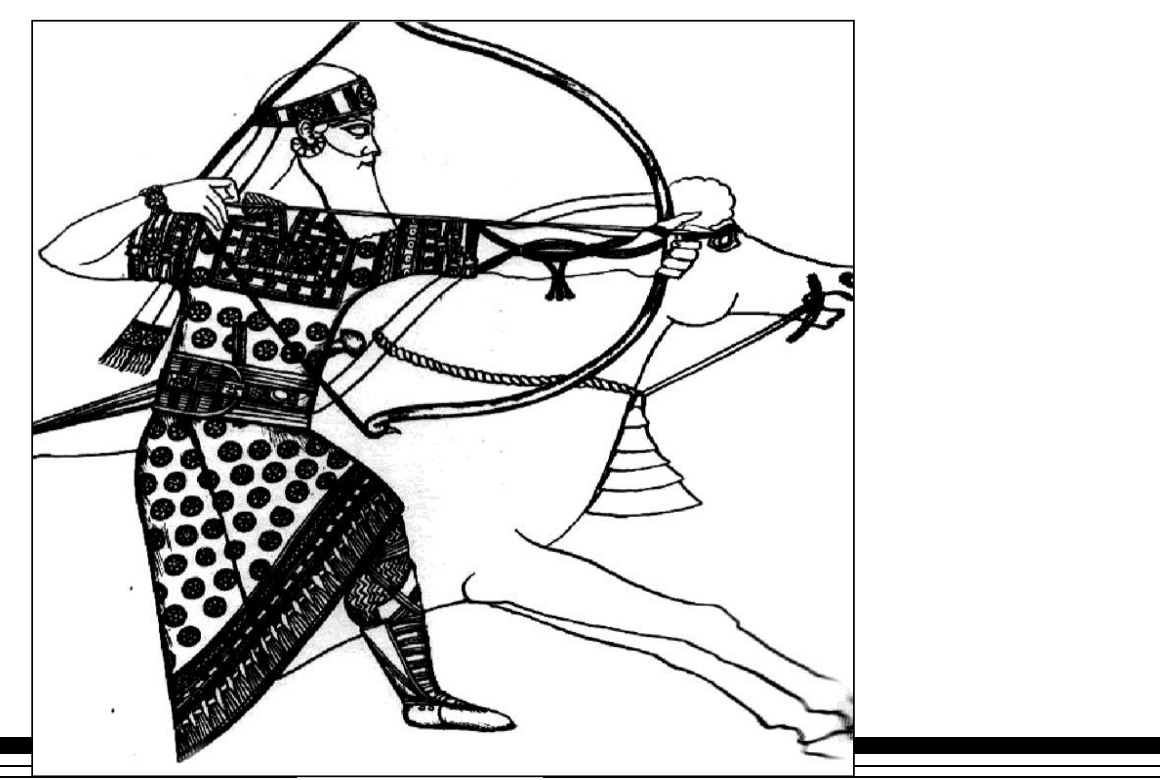




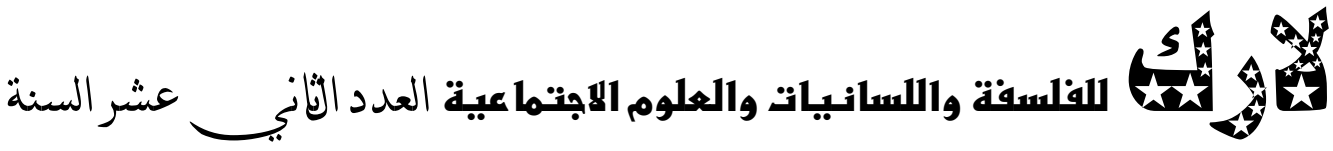
الخامسة2013

$$
\text { شكل (5) يصور الملك (أثور بانبيال) "669-624" }
$$

من خلال ما تقدم نفرض ان لغة خطاب زي الملك بنية تحت طابع ( الديمومة، و البقاء، و الحركة ) المجتمعة تحت قانون ( البساطة )19 لإدر اك الصور في :-

1 - بساطة زي الملك فتحت لنا باب تحديده برداء الحرب، أو الصيد لهيمنة الكل على الجزء.

2 - بساطة زي الملك فتحت باب مقاربة البنية التكوينية لدال زهرة اللوتس الدائرية التكوين بدال حركة يد الملك اليسرى الممدودة بالقوس، وحركة يده اليمنى المثنية بسحب السهم. كما

$$
\text { موضح في مخطط شكل رقم (6). }
$$

3 - بساطة زي الملك فتحت باب جدلية ادر الك الصورة والأرضية استنادآ للمقاربة الخطابية

بين الكل و الأجز اء السابقة الذكر في النقطة أعلاه. فمن مقاربة صورة التكوين الانشائي لحركة يد الملك بالسهم ندرك ارضية الطابع الحركي للخيل الموازي لها فتشير إلبة، ويشير اليها. كما موضح في مخطط شكل رقم (7).

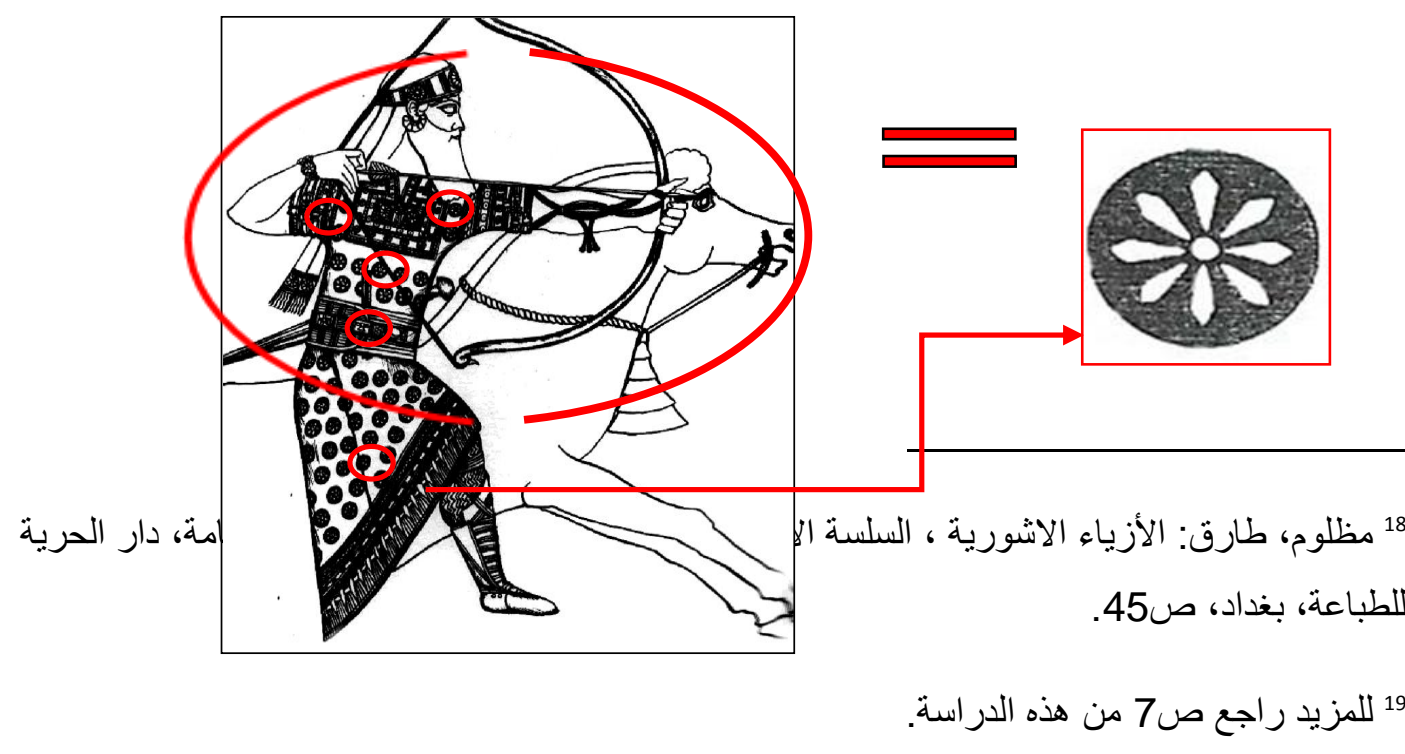




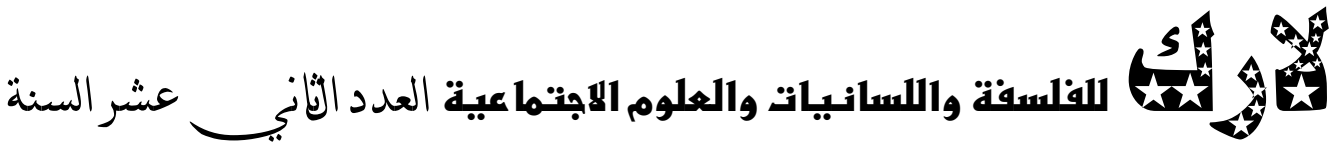
الخامسة2013

شكل (6) يوضح مقاربة دو ال زخرفة الزي اللوتسية بالتكوين الانثائي لحركة الأيدي المتو اشجة مع موضوع الحدث

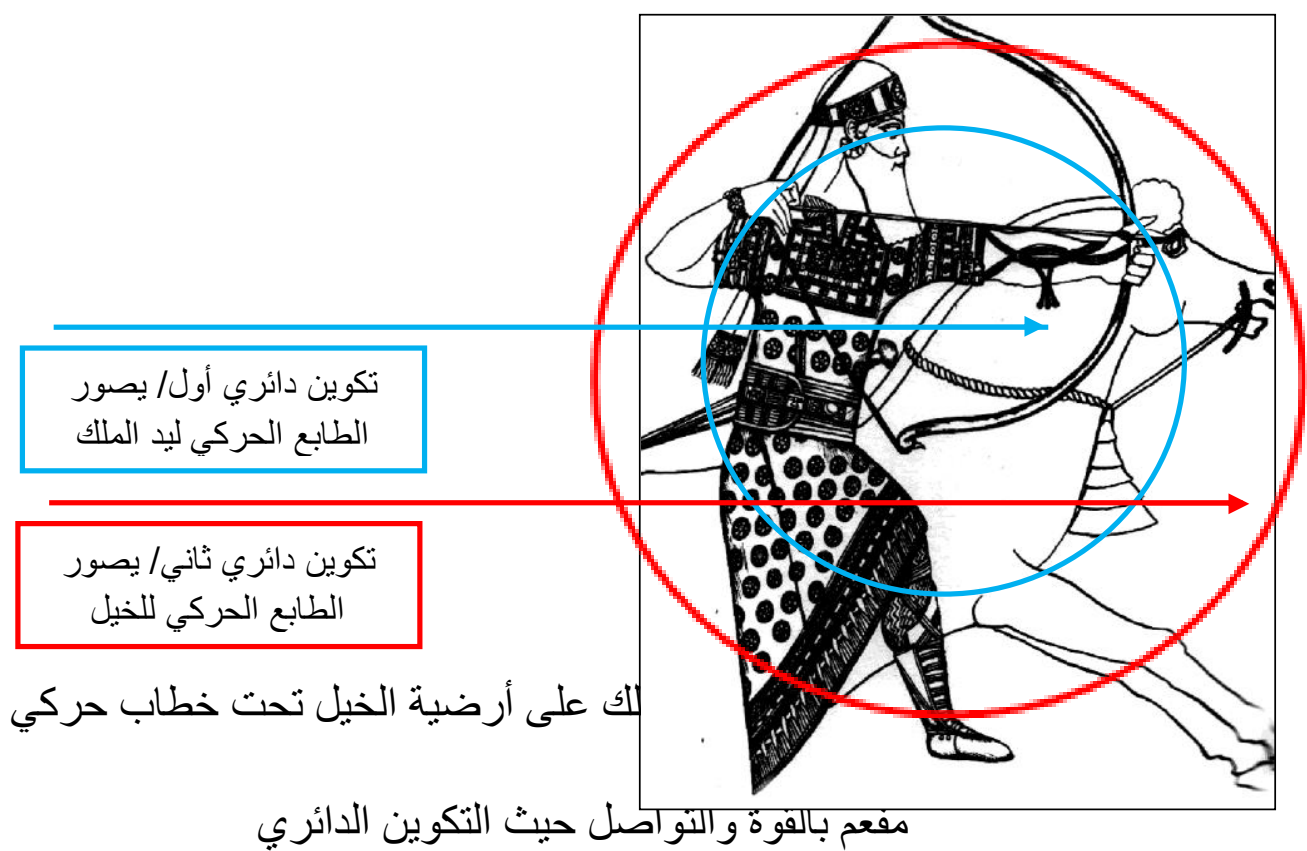

الخطاب الثاني / الملك ( سرجون الثاني ) في بدلة قصيرة فوقها شال طويل توج رأسه بمعصبه مشرشرة من الخلف، وقد حَمل بيده اليسرى و علا مقدسأ، وحَمل بيده اليمنى زهرة اللوتس الكأسية

(8)

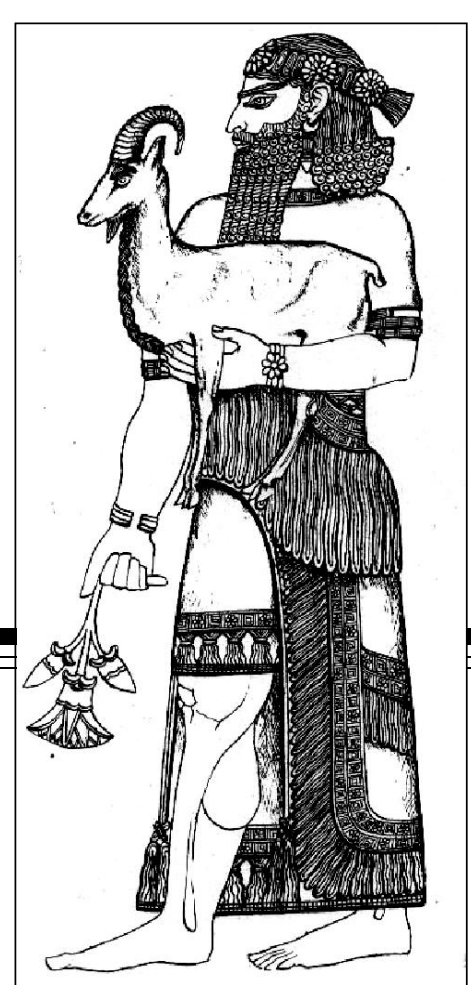
التكوين كما موضح في شكل رقم 


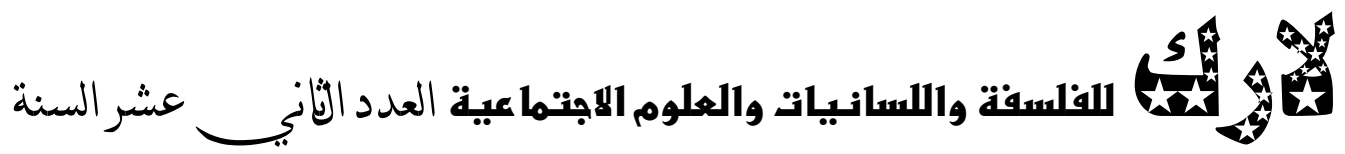
الخامسة2013

$$
\begin{aligned}
& \text { شكل رقم (8) صور الملك (سرجون الثاني) "722 - } 705 \text { " ق.م20 } \\
& \text { هنالك نمط زخرفي منكرر شمل كل من الثال، و القميص في :- }
\end{aligned}
$$

1 - شريط مشرشر معقود من الأعلى طليق من الأسفل ظهر مع دال القميص، وآخر مشرشر

$$
\text { طليق ظهر مع دال الثال. }
$$

2 - شريط آخر يعتلي الثريط المشرشر قام على التتاوب، و التكر ار بين مربعين: شُغل الاول بدال زهرة اللوتس الدائرية التكوين، وشُغل الثاني بدال المربع التكراري. وظف هذا النمط

$$
\text { مع القميص بشريط و احد، ومع الثشال بشريطين. }
$$

كما شمل الطابع الزخرفي السابق الذكر كلا من المكملات البنائية للخطاب في:-

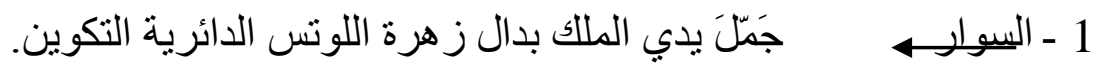

جَمَّت ر أس الملك بدال زهرة اللوتس الدائرية بنمط متناوب مع دال

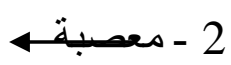

$$
\text { بيضوي متكرر. }
$$

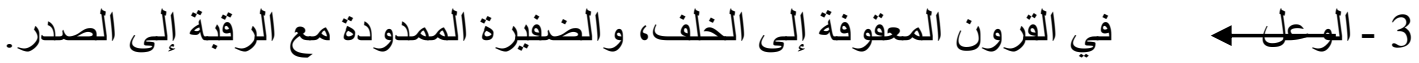

$$
4 \text { - زهرة اللوتســـ في دقة در اسة تفاصبلها الانشائية المورقة. }
$$




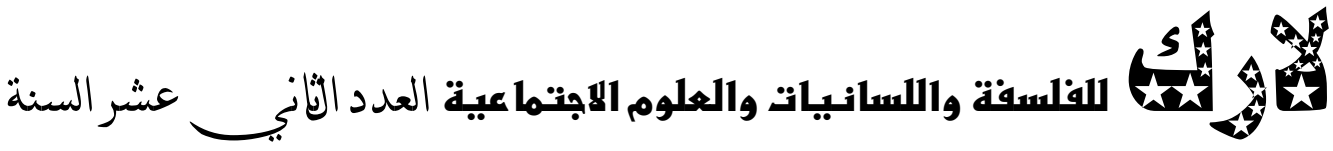
الخامسة2013

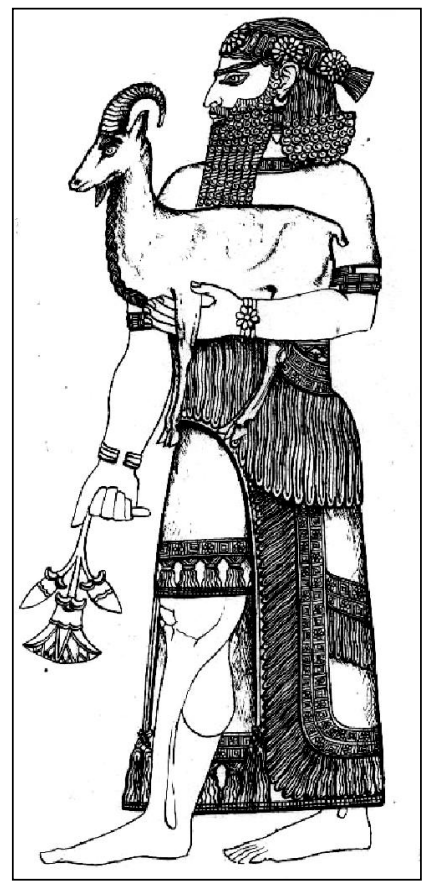

استناداً لما ذكر، يمكن تقديم خطاب زي الملك الثاني بطابع التقديس، و العبادة للعلامات الإشارية الآتية:-

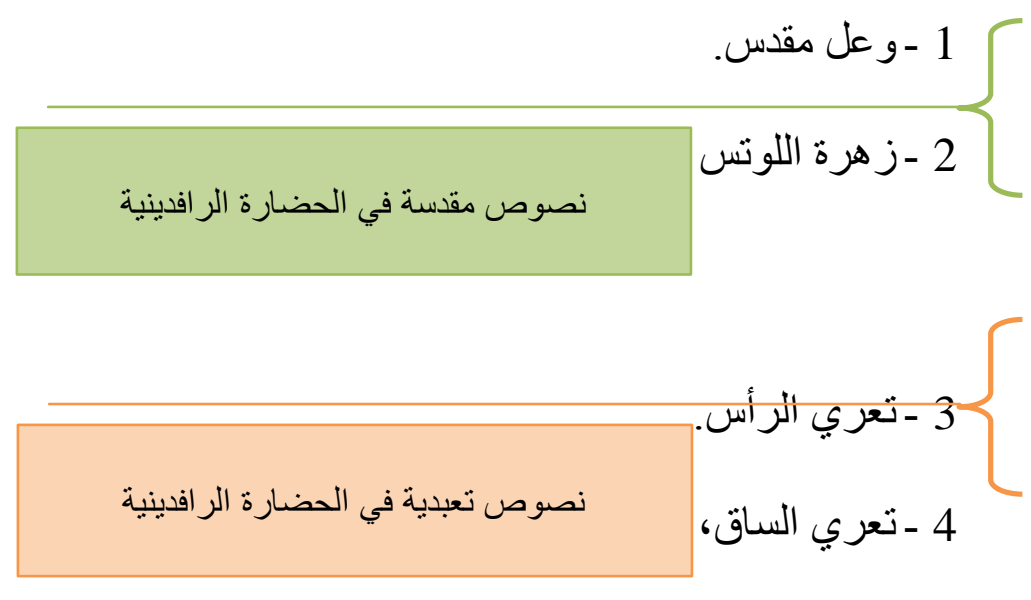

و عليه يمكن تحديد قانون إدر الك خطاب الملك بالاختلاف عبر نصي التقديس، و العبادة المؤكدة من خلال انحناء علامة زهرة اللوتس الكأسية التكوين صوب الأرض. حيث تنقلنا بنية الإختلاف تللك إلى مقاربة الكل بمتقاطعات تتاقضية تشير إلى صر اع الحياة بين القوة، والضعف. الخير ، والثر في :1 - يتقاطع تناقضأ طول الثال مع قصر القميص. 2 - يتقاطع تناقضاً بسط يد الملك اليسرى بالو عل المقس، وقبض يد الملك اليمنى بالزهرة. 3 - يتقاطع تناقضأ ضعف در اسة غطاء الر أس على حساب ابر از در اسة تفاصيل عضلات الساق الايمن. كما موضح في شكل رقم (9). 
الخامسة 2013

نستشف من نلك التناقضات المتقاطعة هيمنة بنية الكل على الجزء تحت تكوين إنشائي ينعقد بعلامة (+) حمل مفهوم الخير 21 المتحقق عبر إدر الك تناقض الحياة في صورة دال الو عل المعطاء 22 على أرضية تجريد صدر الملك من النقوش و الحلي. كما موضح في شكل رقم (10).

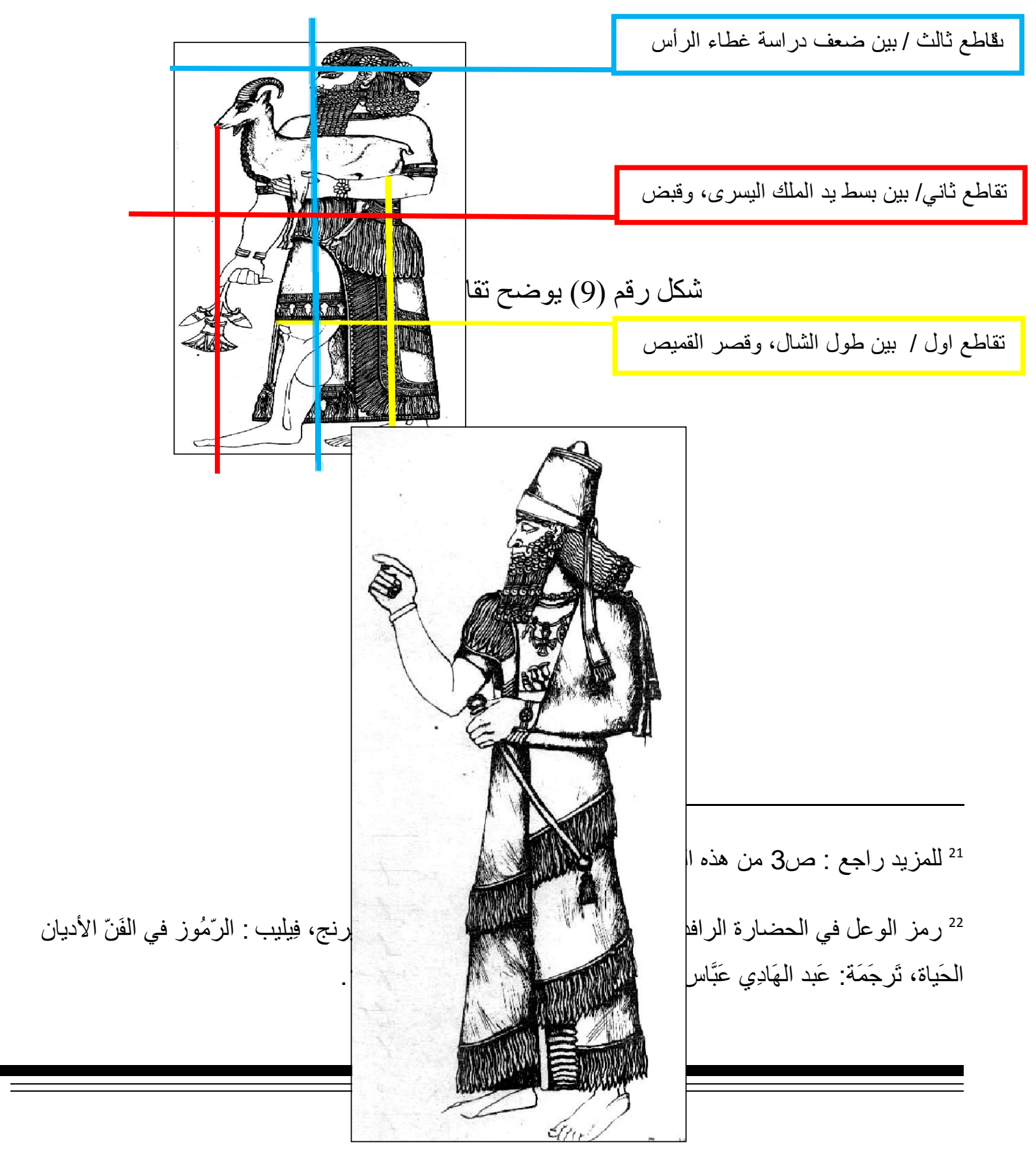




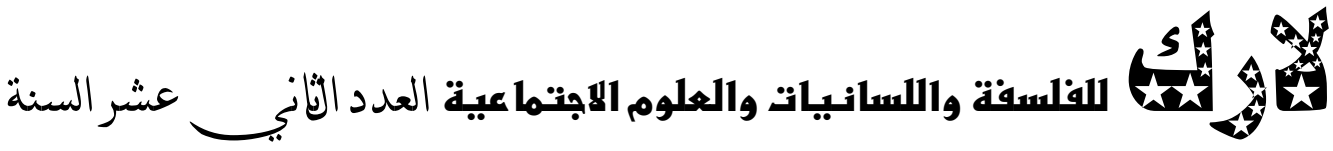
الخامسة2013

شكل رقم (10) يوضح إدر الك صورة عطاء الوعل على أرضية الملك المجردة

الخطاب الثالث / يرتدي الملك ( أشور ناصر بال ) بدلة طويلة ذات ثناث طيات ملتفة حول الجسد وقد زينت نهاياتها بشر اشير طليقة. كما زين غطاء ر أسه بعمامة مخروطية التكوين بتدلى منها شريطان طويلان مشرشر ا النهايات. أنظر شكل رقم (11). شكل رقم (11) يصور الملك (أشور ناصر بال) "883- 859" ق.م 23

أرضية صماء خالية من الرموز

صورة معطاء بعلاماتها البنائية في القرون + و الضفيرة 


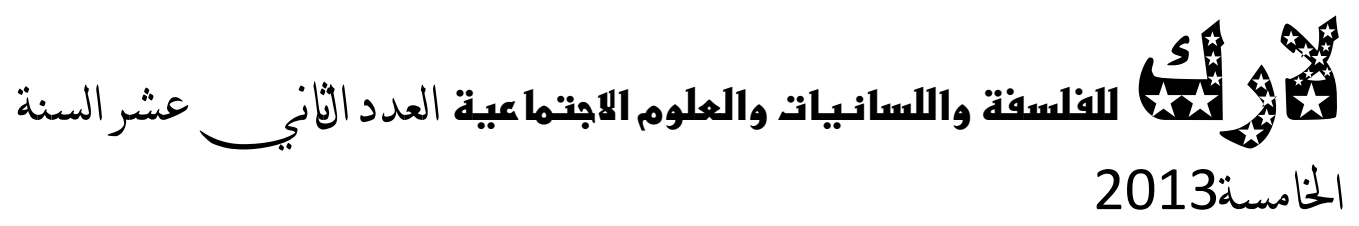

إن البحث في البنية الكلية حيث المسح البصري للعمل الفني فتح لنا باب در اسة تفاصيله الجزئية في:-

$$
1 \text { - تتويج عمامة الملك بتكوينُ قبيج. أنظر شكل رقم (12 أ). }
$$

2 - تجميل رقبة الملك برموز معبوديه لكل من معبود الصواعق ( أدد )24. أنظر شكل رقم

$$
\text { (12- ب)، ومعبود العدل ( إنليل )25. أنظر شكل رقم (12- ج). }
$$

3 ـ تجميل يد الملك اليسرى بزهرة ( اللوتس )26 الدائرية التكوين حيث رمز المعبودة عشتار.

$$
\text { انظر شكل رقم (12 - د). }
$$

4 - نتويج صولجان حكم الملك بتكوين كوكبي. لاحظ شكل رقم (12- هـ).

${ }^{24}$ Balck, Jeremy and Anthony Green: Gods Demons and symbols of Ancient Mesopotamia an Illustrated Dictionary, (Illustrations) Tessa Rickards, London: British Museum, 1992, p, 118

$$
25 \text { خَزَعل المَاجدي، إنجيل سومر ، ص } 17 .
$$

${ }^{26}$ Balck, Jeremy and Anthony Green: Gods Demons and symbols of Ancient Mesopotamia an Illustrated Dictionary, p156. 
الخامسة2013
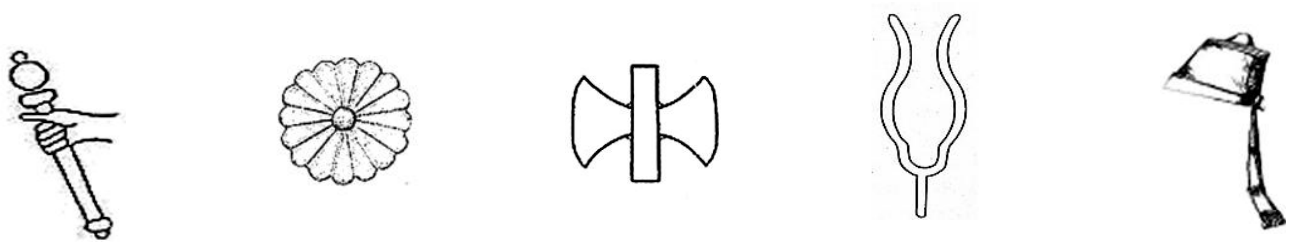

(ه)

(د)

(ج)

$(\varphi)$

شكل رقم (12) يوضح در اسة لتفاصيل العمل الفني

على غرار ما ذكر سابقا، تظهر عندنا مقاربة بنائية بين البنية الكلية، والوحدات الجزئية في تحديد خطاب زي الملك بالسلطة في خمس علامات إنشائية لرموز المعبودات 27، و الموجودة على قبة مسلة ( أشور ناصر بال ) . انظر شكل رقم (13)

27 اخذت هذه القر اءة من خلال الاطلاع على كم من المصادر نذكر ها : المَاجدي، خَزعَل، إنجيل بابل، ط1، لبنان:

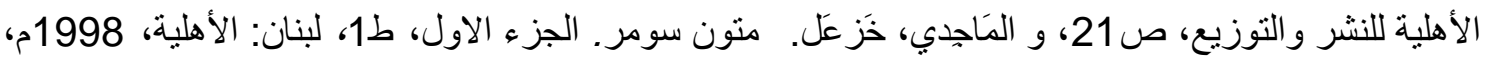

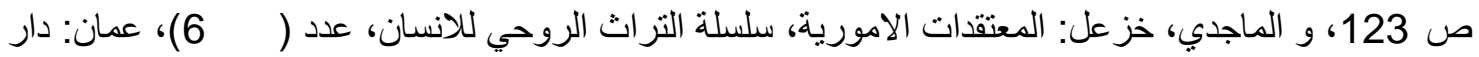
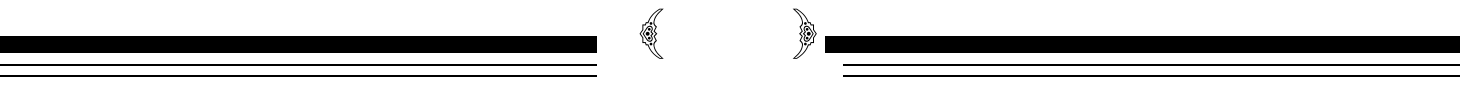
الخامسة2013

استنادا لما ذكر سابقا سيتم تحديد قانون إدر الك الفضاء لبنية خطاب الملك و القائم على العظم بو اسطة متحدين :-

1 ـاتحاد عمامة الملك مع صولجان الحكم في علامة التقبيب المشيرة إلى الكون، و السماء. 2 ـاتحاد قلادة الملك مع رموز المسلة في علامات المعبودات الكونية (الرعد، والقمر،

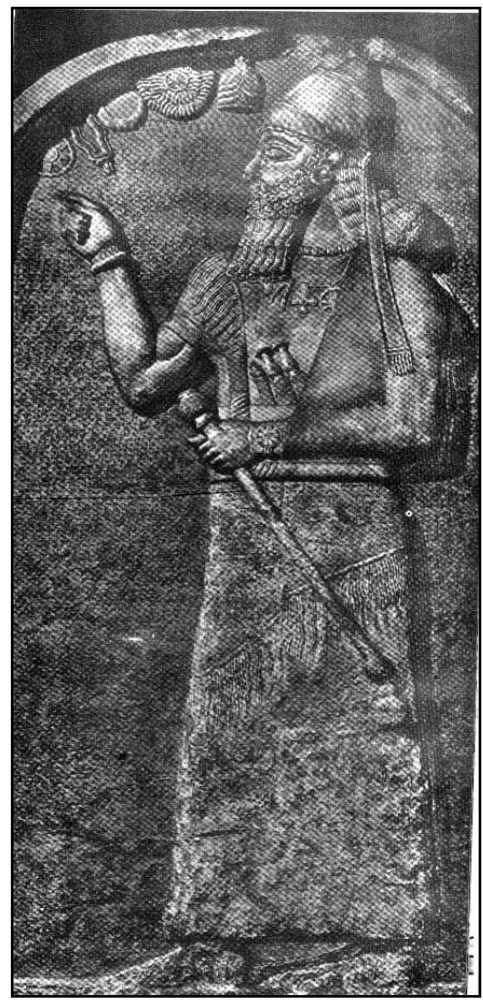

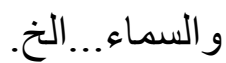

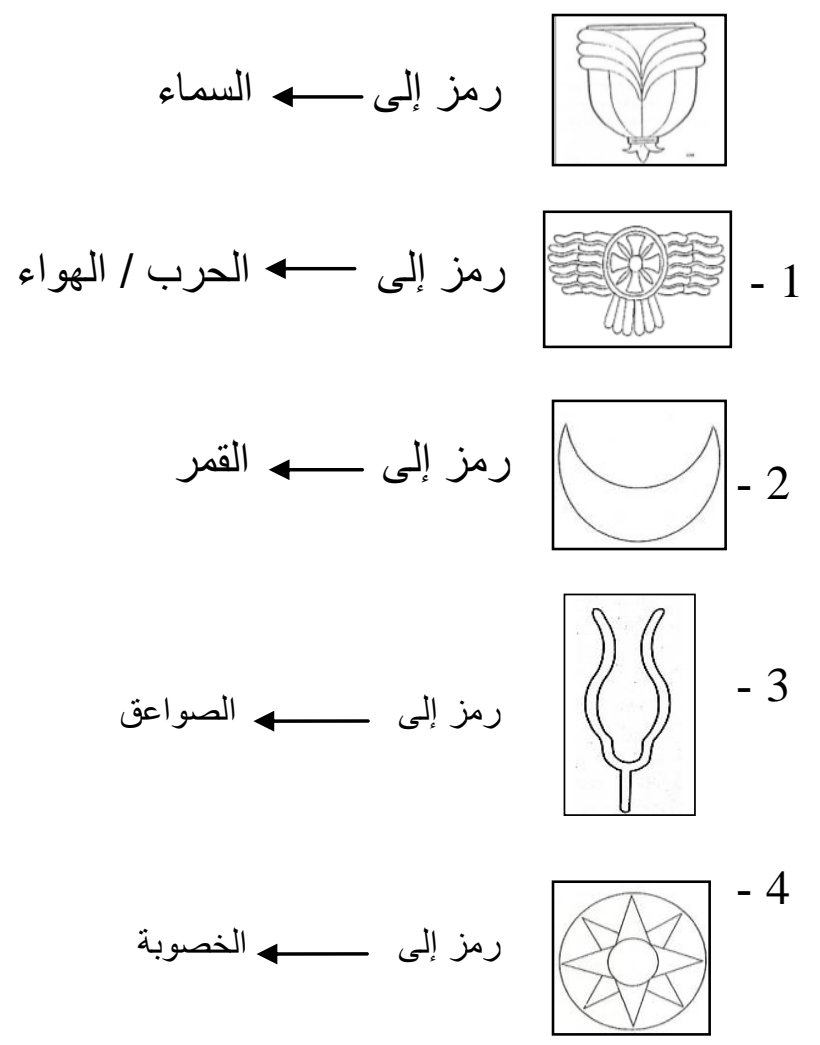

Balck, Jeremy and Anthony Green: Gods Demons and الشروق للانتاج والتوزيع، 2002م، ص73، و symbols of Ancient Mesopotamia an Illustrated Dictionary,p169
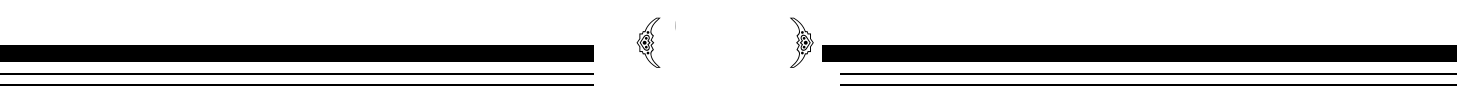
الحنامسة2

شكل (13) مسلة الملك ( أشور ناصر بال )28

مما مضى نتوصل إلى تحقيق قانون إدر الك البنية الخطابية لزي الملك في ( السلطة، والعظمة ) من خلال تناوب ظهور الصورة والأرضية بين دالي المربع 29 :1 - مربع ذو قمة محدبة برموز المعبودات الكونية حيث بنية المسلة. 2 - مربع ذو قمة مقعرة برموز المعبودات الكونية حيث بنية الزي.

فلا يمكن حذف أحدهما أو إخفائه، فلو لا وجود الأرضية لما أدركت الصورة، كذلك لو لا وجود الصورة لما أدركت الارضية؛ لذلك استعان الفنان الر افديني على ما يبدو بأصبع التأثير ليد الملك اليمنى كو اسطة اتصالية بين المربعين. كما موضح في شكل رقم (14).

شكل رقم (14) يوضح تناوب ظهور خطاب زي الملك بين مدرك الصورة و الارضية

28 بارو، أندريَّة: بلاد آنشوُر، (تَرجمة وتَعليق)، عيسَى سَلمان، وسَليم طه التكريني، بغداد: دار الحرية، 1980م، ص28، 29 للمزيد راجع مدلول المربع في الحضارة الر افدينية ص3 من هذه الدراسة. 


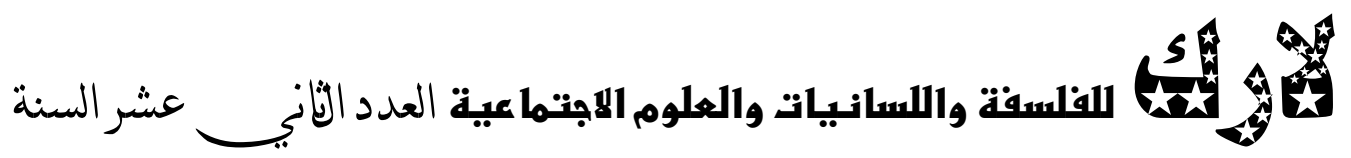
الخامسة2013

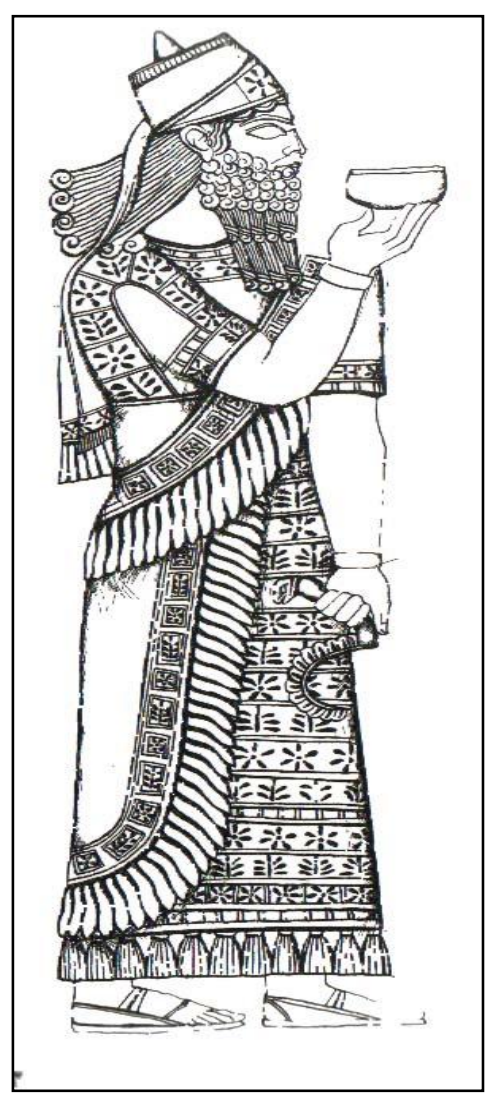

الخطاب الرابع / يصور الملك ( أثنور ناصر بال ) برداء مؤلف من قطعتين وهما قميص طويل فوقه شال طويل أيضأ، وتوج ر أسه بعمامة مخروطية الشكل. انظر شكل رقم (15). 


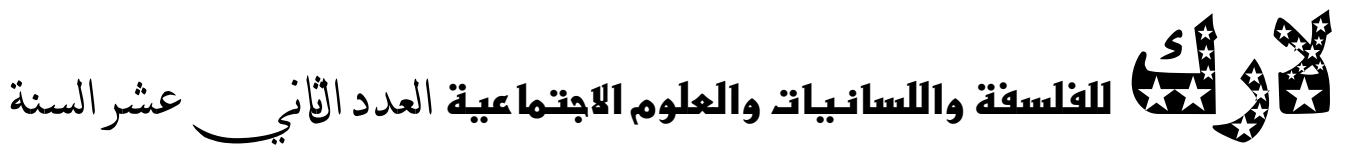
الخامسة2013

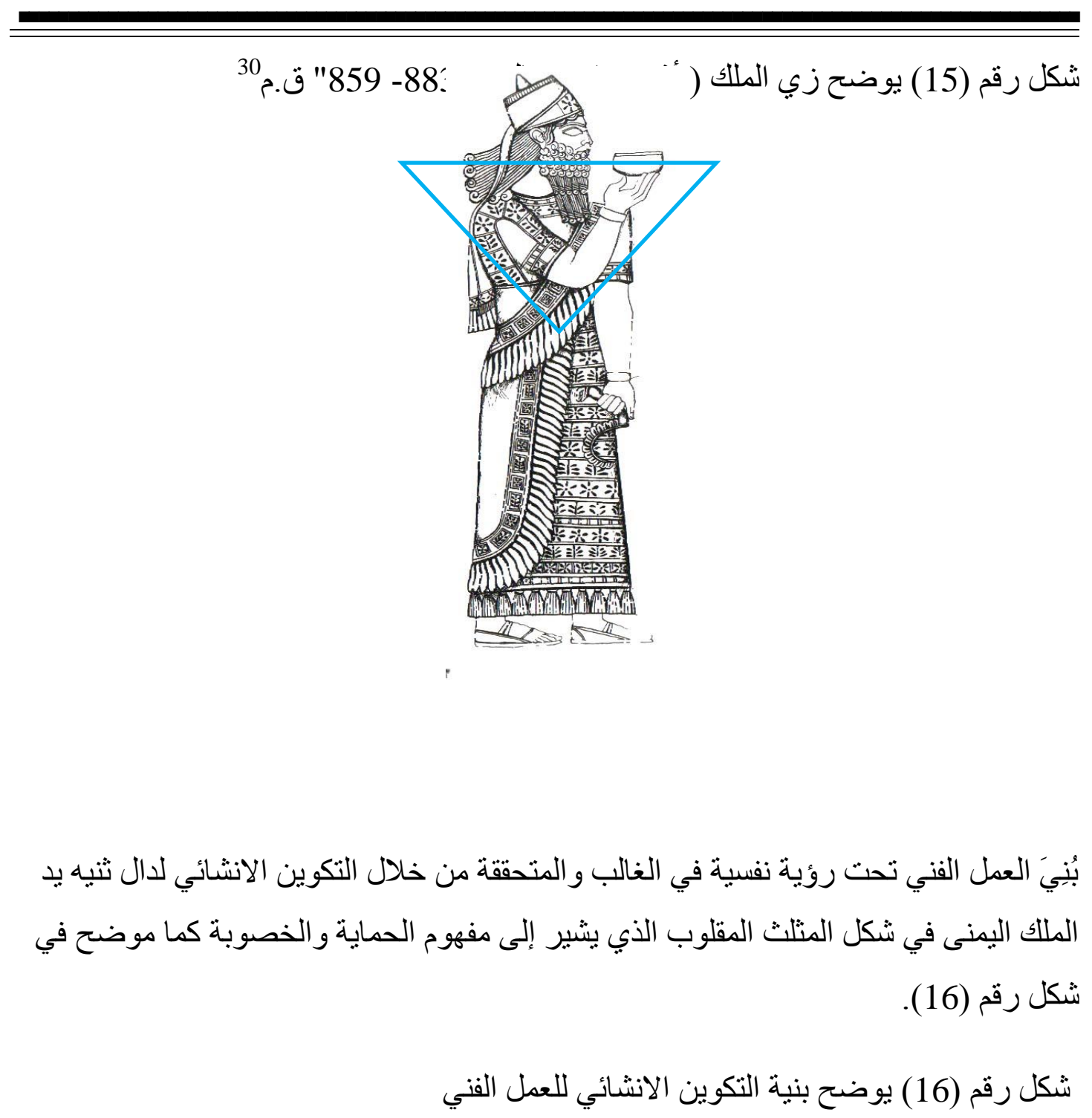

${ }^{30}$ Balck, Jeremy and Anthony Green: Gods Demons and symbols of Ancient Mesopotamia an Illustrated Dictionary, p95. 
الحنامسة2013

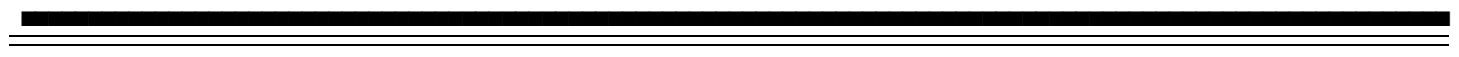

مربع محدب برموز المعبودات = أرضية

مربع مقعر برموز المعبودات = صورة

تظهر المقاربة العلامية بين الجزء والكل في تو اكب بنية خطاب الزي مع مدلول العطاء في :-

$$
\begin{aligned}
& 1 \text { ـ دال الكأس + الماء31 = احتو اء. } \\
& 2 \text { ـ دال المنجل } 23 \text { + افعى } 33 \text { = الحياة. }
\end{aligned}
$$

31 رمز الماء في الحضارة الر افدينية إلى مدلول القوة، والحياة، والنشاط المتجدد، والانتعاش. للمزيد راجع : محمود، المين،

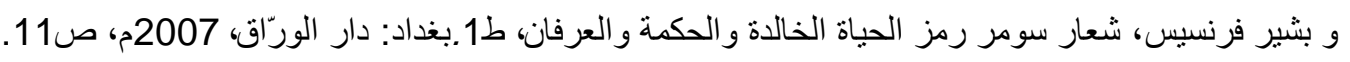

32 قارب دال المنجل مدلول الثُمس المعطاء في الحضارة الر افدينية لانهما رمزا إلى المعبود (شمش). للمزيد راجع: خَزعل المَاجدي، إنجيل بابل، ص15. 


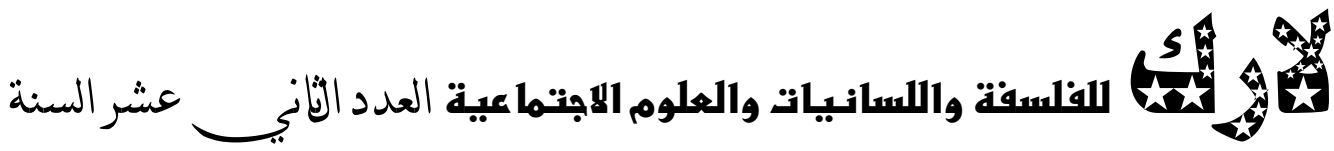
الخامسة2013

و عليه يتحقق إدر اكك صورة الزي الآشوري على أرضية الحياة في تناوب ظهور حركة الأبدي بين

انثناء اليد اليمنى بكأس الحياة، ومد يد الملك اليسرى بمنجل الخلود. فلو لا وجود البد اليمنى لما تحقق إدر الك الأخرى، وبالعكس كلاهما تبنيان الأخرى كما موضح في شكل رقم (17).

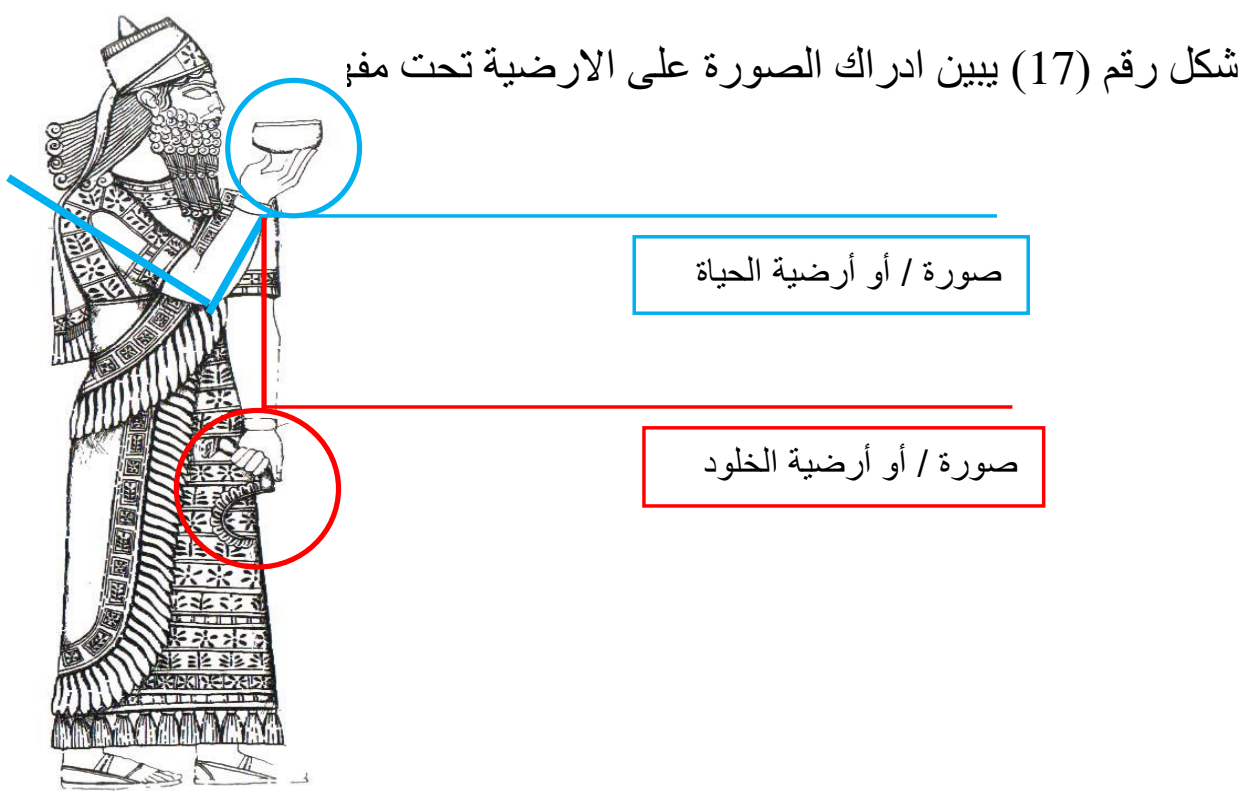

إنّ البحث في المدركات الصورية مهد لنا تحديد قانون إدر الك فضاء بنية خطاب زي الملك و القائم على تطبيق صورتي الانتظام و التقابل من خلال الطابع الحركي و التكوين الانشائي، فضلا عن المصففات الزخرفية للزي صورت هي الأخرى بنمطين:-

33 ترمز الافعى إلى الحباة في الحضارة الر افدينية . للمزيد راجع: سبرنج، فِيليب. الرّمُوز في الفَنّ الأديان الحَباة، ص116. 


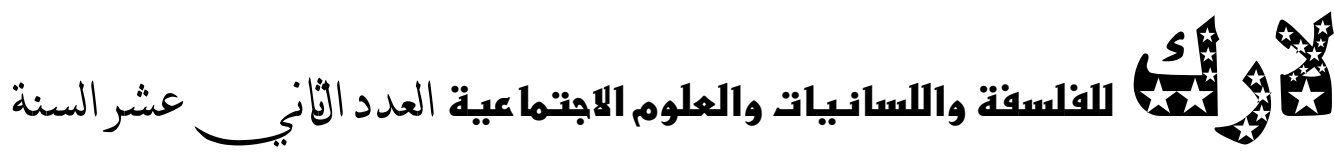
الخامسة2013

1 ـ نمط حقلي التكوين أفقي البناء متكرر، ومتناوب بين حقل لدال زهرة اللونس الدائرية

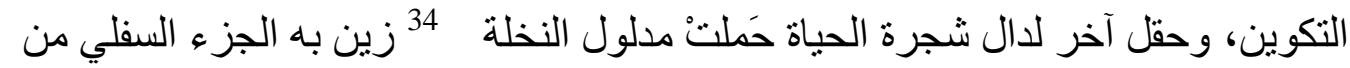
القميص.

2 ـ نمط مستطيلي التكوين أفقي، و عمودي البناء التكراري، ومتناوب الصور بين مستطيل لدال

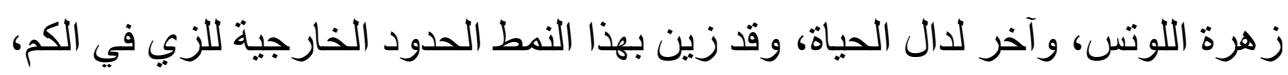

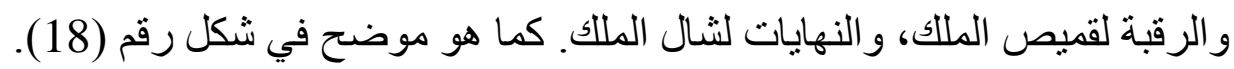

كما شمل القانون نمطية توزيع شر اشير الزي في صورتين:1 ـ النموذج الاول زين نهاية القيص بشريط مشرشر من الخيوط المعقودة من الاعلى في شكل حُزَمْ طليقة من الاسفل. 2 ـ النموذج الثاني زين نهاية الثال بشريط مشرشر بخيوط مهدبة طليقة غير معقودة.

34 تزين الملابس الآتشورية شجرة مقسة وهي عبارة عن نخلة في الغالب مؤدى بشكل واضح أو طبيعي وفي

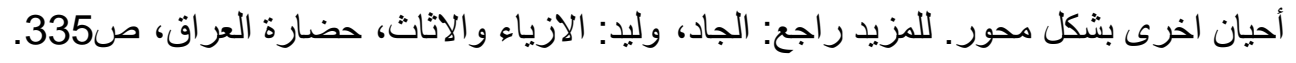




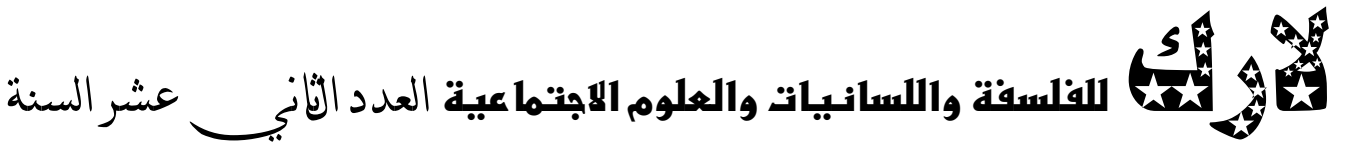
الخامسة2013

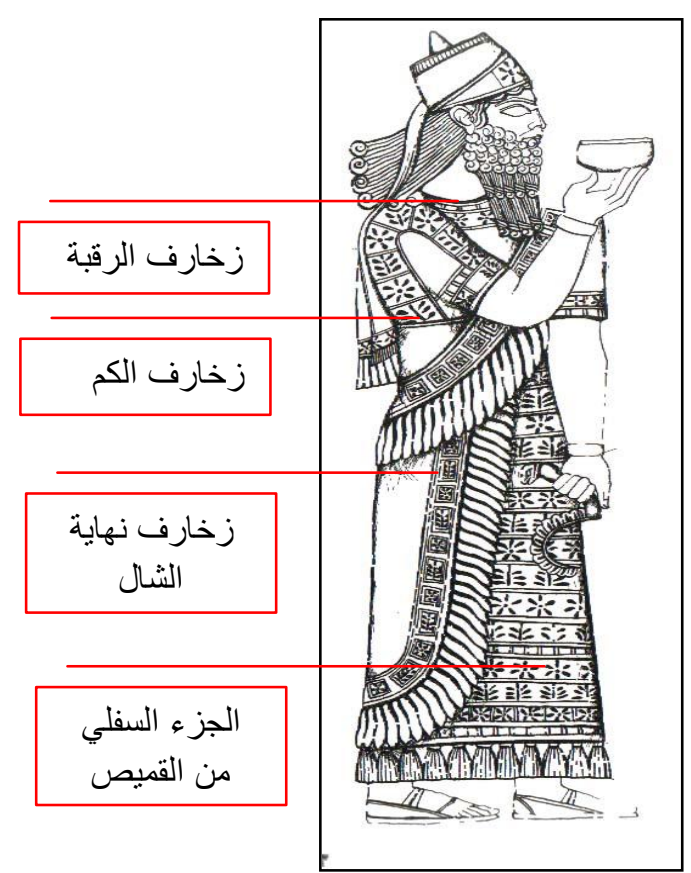

شكل رقم (18) بوضح الزخارف النباتية للزي

وقد شمل هذا القانون مرة أخرى نمطية ترتيب عمامة الملك في ثناث قطع:1 - قطعة اسطو انية التكوين ضيقة من الأعلى عريضة عند القاعدة شغلت الجزء السفلي من العمة.

2 - قطعة مخروطية التكوين مدبية النهاية شغلت الجزء العلوي من العمة.

3 - معصبة ر أس عريضة من الامام ضيقة من الخلف تنتهي بشريط طويل معقود مشرشر ، و مزين بدال زهرة اللوتس الدائرية التكوين كما شغلت هذه الزهرة مقدمة المعصبة المزينة للقطعة الاسطو انية كما هو موضح في شكل رقم (19). 


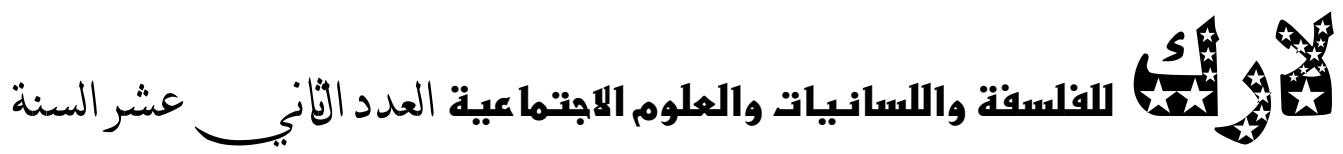

الخامسة2013

شكل رقم (19) يصور عمامة الملك ( أثور ناصر بال)

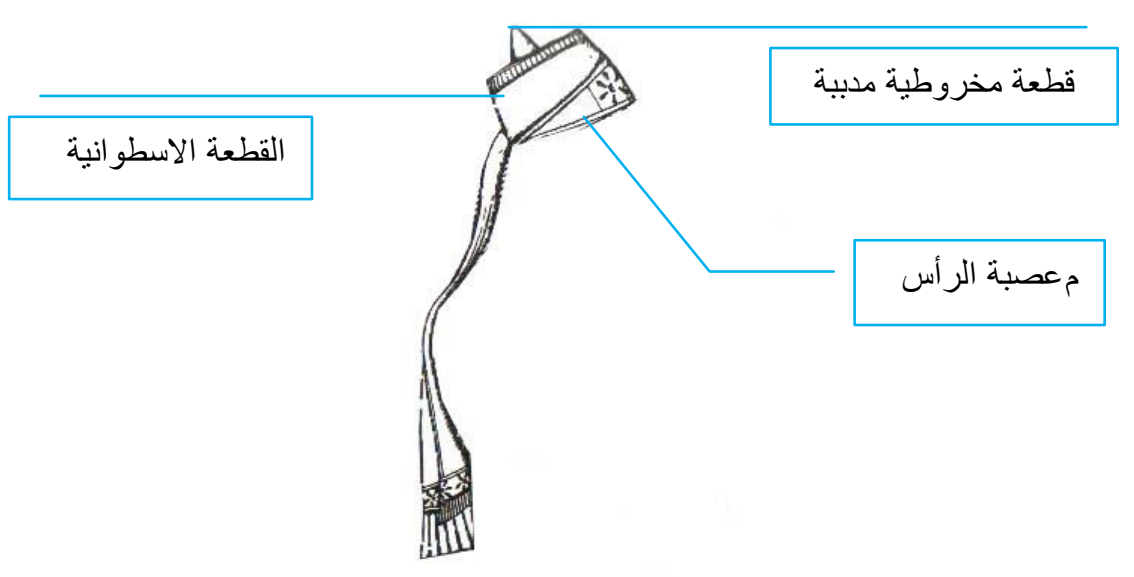

نتائج الار اسة :-

إنّ خطاب لغة الزي الآشوري بني تحت إمرة الحدث الضاغط، فقد يظهر للدال الو احد أكثر من صورة إنشائية حيث حاكى رداء الملك رداء الجندي في الحرب، ورداء الحاكم في السلطة، ورداء التعبد عند العبادة، ورداء الخلود في الطقوس السحرية. كما هو موضح في ادناه:1 ـ الملك بزي الحربـــ بني خطابه الإنشائي على وفق قانون البساطة.

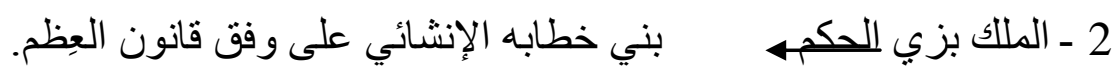




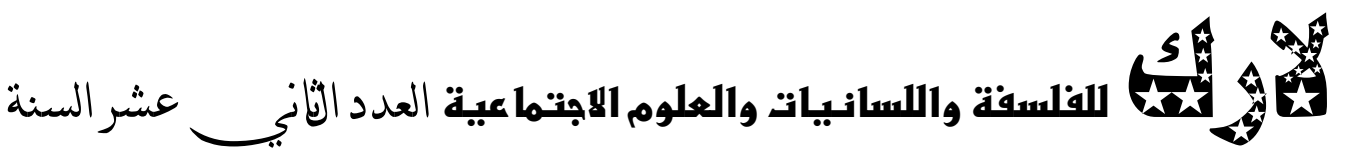
الخامسة2013

3 ـ الملك بزي المعبلده بني خطابه الإنشائي على وفق قانون الاختلاف.

4 ـ الملكك بزي الخلودـــ بني خطابه الإنشائي على وفق قانون الانتظام، و التقابل. 